\title{
O orçamento e os gastos públicos da saúde na esfera federal no capitalismo contemporâneo no Brasil
}

Recebid o: 5 out. 2020

Aceito: 21 out. 2020

Autor de correspondência: Marilene Gonçalves Franca mgfrancaenf@gmail.com

Conflito de interesses: As autoras declaram não haver nenhum interesse profissional ou pessoal que possa gerar conflito de interesses em relação a este manuscrito.
Marilene Gonçalves FRANÇA: Pós-Graduação em Saúde Coletiva, Universidade Federal do Espírito Santo - UFES. ORCID: https://orcid.org/0000-0002-4712-9907

Adriana Ilha da SILVA: Universidade Federal do Espírito Santo - UFES, Programa de Pósgraduação em Saúde. ORCID: https://orcid.org/0000-0001-8698-5768

Francis SODRÉ: Universidade Federal do Espírito Santo - UFES, Programa de Pós-graduação em Saúde Coletiva. ORCID: https://orcid.org/0000-0003-4037-9388

\section{Resumo}

A saúde foi instituída como direito de cidadania na Constituição Federal de 1988 (CF/88) possibilitando que muitos cidadãos que não tinham acesso as ações e serviços de saúde passassem a usufruí-lo. Contudo, a garantia de recursos financeiros suficientes para assegurar esse direito constitucional tem se constituído um processo complexo, considerando a especificidade histórica, política, econômica e social de cada ente federado, atrelado a capacidade de arrecadação tributária instalada em cada estado ou município, a dependência de transferências dos recursos da União e o poder de alocação de recursos próprios na materialização das políticas de saúde. Nesse processo a apropriação do fundo público tornou-se uma disputa política entre o capital e os direitos sociais, estabelecendo uma correlação de forças na esfera política. Na consolidação do capitalismo, o fundo público tornou-se primordial, sendo os recursos públicos elementos de sustentação dos mercados financeiros, ao mesmo tempo, financiador do capital portador de juros. Já na proteção social o fundo público é o elemento principal no financiamento das políticas sociais. Nesse contexto, os direitos sociais estão sendo ameaçados e reduzidos pelas contrarreformas que o estado capitalista vem adotando nessa fase contemporânea de capitalismo financeirizado e de ajuste fiscal. O governo federal vem se apropriando das contribuições sociais destinadas à seguridade social, resultando no esvaziamento permanente do seu financiamento, deixando os recursos públicos liberados para os condutores das políticas econômicas atenderem os interesses do capital e não aos princípios de universalidade, integralidade e equidade do SUS. No decorrer dos anos, esses recursos, têm financiado as crises do capital e os ajustes fiscais têm limitado os direitos sociais, ao invés de consolidar o Estado Social - de direitos- e estruturar o financiamento da seguridade social. Para compreender as restrições impostas às políticas sociais e os cortes orçamentários, e consequentemente o (des)financimento do SUS é preciso analisar a relação do capital com o fundo público, a fim de entender os entraves para consolidação dos direitos sociais, num contexto de financeirização da economia e de captura do fundo público pelos interesses do mercado que fragiliza a implementação das políticas sociais. Busca-se neste estudo analisar a relação entre orçamento público e fundo público, por meio da análise da execução orçamentária da União no período entre 2009 a 2019, a partir de um comparativo entre o gasto público com saúde e o montante destinado ao pagamento dos juros e amortização da dívida pública brasileira. Trata-se de um estudo documental de caráter exploratório descritivo baseado nas informações obtidas pelo Relatório Resumido da Execução Orçamentária do governo federal e outros demonstrativos, disponível no portal do Tesouro Transparente, canal de disponibilização das informações consolidadas pelo Tesouro Nacional no período de 2009 a 2019 . Os dados 
foram organizados em dois tipos de despesas: gasto público com saúde, subdivididos em gasto público com Ações e Serviços Públicos de Saúde (ASPS) e gasto público não ASPS (despesas não computadas com saúde) e o gasto com juros e amortização da dívida da União, após foram calculadas as variações percentuais por ano. Posteriormente, foi traçado a evolução do gasto público com saúde, comparando-o com o valor gasto para pagamento de juros e amortização da dívida pública. O valor foi corrigido pelo Índice Nacional de Preços ao Consumidor Amplo (IPCA) de dezembro de 2019. No período de 2009 a 2019, o gasto público com saúde da União passou de $R \$ 103.134 .977,54$ milhões em 2009, para $R \$$ 114.066.592,01 milhões, em 2019, apresentando aumento percentual de 12,39\%. Em relação ao gasto público com gasto com Ações e Serviços Públicos de Saúde (ASPS) houve um aumento de $10,59 \%$, enquanto o gasto público com não ASPS teve crescimento de $65,21 \%$, demonstrando que os gastos com ações que não são computadas na saúde ao longo do período apresentaram um maior crescimento. Comparando os gastos públicos com saúde com os gastos com juros e amortização da dívida da União, observa-se que ao longo dos últimos dez anos, os gastos desses últimos sempre se mantiveram acima do referente ao da saúde. No ano de 2009, a União apresentou valor de $R \$ 2.580 .982 .335,62$ trilhões de reais do orçamento executado. No que tange o gasto público com saúde foi de $R \$ 111.342 .456,33$ milhões de reais (que representou 4,31\% do orçamento da União executado) enquanto o valor gasto com juros e amortização da dívida foi de $R \$$ 470.083.614,39 milhões de reais (que representou $18,21 \%$ do orçamento executado da União). No ano de 2019, o gasto público com saúde foi de $\mathrm{R} \$ 127.626 .290,66$ milhões de reais (que representou 4,33\% do orçamento da União - executado), por sua vez o valor gasto com juros e amortização da dívida foi de $R \$ 482.258 .160,32$ milhões de reais (que representou $16,37 \%$ do orçamento executado da União). Desse modo, observa-se que um percentual maior do fundo público foi direcionado para pagamento dos juros e da amortização da dívida pública, em detrimento a política de saúde. O financiamento das políticas sociais é um reflexo da atual conjuntura política e econômica no país, na qual estão inseridos os interesses de reduzir a máquina pública por meio dos cortes dos gastos com os direitos sociais, desmontando seu aparato social e preservando a lógica do mercado. O Estado, nesse sentido, captura o fundo público para o financiamento do capital portador de juros, que transferem os recursos sociais para amortização dos juros da dívida e superávit primário, e são responsáveis pela não efetivação do orçamento público com a saúde, conforme previsto no texto constitucional, caracterizando o (des)financiamento e o desmantelamento do SUS. Assim, a política de saúde, não foi priorizada no orçamento público para a efetivação dos direitos sociais e os recursos públicos que deveriam compor o financiamento da saúde têm sido desviados pelas políticas macroeconômicas restritivas, subsidiando e financiando a acumulação capital, ao invés de financiar as políticas sociais. Essa situação vem caracterizando o desmonte do Estado e dos direitos sociais, privilegiando a rentabilidade econômica e financeira.

Descritores: Gastos em Saúde; Orçamento; Capitalismo; Política de Saúde.

Keywords: Cost Control; Budgets; Capitalism; Health Policy.

Palabras-claves: Control de Costos; Presupuestos; Capitalismo; Política de Salud. 